\title{
First record of the pantropical blue tick Rhipicephalus microplus in Namibia
}

\author{
Nkululeko Nyangiwe $\bullet$ Conrad Matthee $・$ Ivan Horak $•$ Sonja \\ Matthee
}

\begin{abstract}
The invasive pantropical blue tick, Rhipicephalus microplus, has recently been collected from cattle in Namibia. A cross-sectional study aimed at recording the geographic distribution of Rhipicephalus decoloratus and establishing whether R. microplus is present in Namibia was conducted towards the end of summer (March-April) 2013. Ticks were collected from cattle on 18 privately owned farms across a large geographical scale. Ticks were collected from three to five cattle per farm and species belonging to the genera Hyalomma and Rhipicephalus were recovered. Rhipicephalus decoloratus was present on all farms and $R$. microplus was recorded on four of the farms. The small numbers of $R$. microplus compared to $R$. decoloratus collected in the mixed infestations, suggests that the introduction events were recent.
\end{abstract}

Keywords $\quad$ Cattle $\bullet$ Rhipicephalus microplus $\bullet$ Ticks $\bullet$ Namibia

N. Nyangiwe $\bullet S$. Matthee (Correspondence author)

Department of Conservation Ecology and Entomology, Stellenbosch University, Private Bag X1, Stellenbosch 7602, South Africa

e-mail: smatthee@sun.ac.za

N. Nyangiwe

Dohne Agricultural Development Institute, Private Bag X15, Stutterheim 4930, South Africa

C. Matthee

Department of Botany and Zoology, Stellenbosch University, Private Bag X1,

Stellenbosch 7602, South Africa

I. Horak

Department of Veterinary Tropical Diseases, University of Pretoria, Private Bag X04,

Pretoria 0110, South Africa

I. Horak

Department of Zoology and Entomology, University of the Free State,

Bloemfontein 9301, South Africa 
Livestock farming is one of the primary contributors to the agricultural sector and the main source of rural livelihood in Namibia (Lange et al. 1997). Currently approximately $75 \%$ of the country's total land area is allocated to livestock farming, with more than $40 \%$ used for commercial cattle farming (Lange et al. 1997). Data from the Namibian Livestock Sector Strategy, Final report (published in December 2011) indicates that for the year 2010/2011 the estimated contribution of the producer value in terms of slaughtering for export or for local consumption and live exports was approximately 2 billion Namibian dollar (N\$). Export to neighbouring countries (South Africa and Angola) and Europe contributes significantly to the income generated from cattle production (Namibia Meat Board Chronicle 2013).

Tick records for Namibia date back to the 1890s with subsequent studies expanding on the species lists. Howard (1908) records five ixodid species from Namibia, amongst them Rhipicephalus decoloratus, which at the time he referred to as Margaropus annulatus var. decoloratus. In his synoptic check-list and host-list of the ectoparasites found on South African Mammalia, Aves, and Reptilia, Bedford (1932) recognizes eight ixodid tick species present in Namibia, while 30 years later this number had increased to 28 species (Theiler 1962). In 2000 five more Rhipicepalus species were added to Theiler's list (Walker et al. 2000). With the data at hand it is clear that a diverse assemblage of tick species, including several species of Rhipicephalus, exist in the region. From the foregoing it is also evident that comprehensive sampling may indeed reveal a higher species richness for the region.

Theiler (1949) plotted the distribution of the regionally common R. decoloratus, which she then referred to as Boophilus (Palpoboophilus) decoloratus, in South Africa. In addition, she also listed the localities at which it had been collected in Namibia. Similarly in her treatise on the ticks of vertebrates in Africa South of the Sahara Theiler (1962) lists the localities at which the 28 species she records for Namibia were collected. However, besides Theiler's records and the maps published by Walker et al. (2000) on the distributions of the various Rhipicephalus species of the world, in which Namibia was included, little is known about the distribution of tick species in the country.

The invasive success of Rhipicephalus microplus has contributed to its widespread distribution with records that include countries in Latin America and also Mexico, Australia and Madagascar (Estrada-peña et al. 2006). On the African continent R. microplus is common along the eastern coastal belt and also in the summer rainfall northern regions of South Africa (Howell et al. 1978; Tennesen et al. 2004; Horak et al. 2009; Spickett et al. 2011). It is also present in Swaziland, Mozambique, Zimbabwe and Zambia (Mason and Norval 1980; Berkvens et al. 1998; Wedderburn et al. 1999; Horak et al. 2009). Furthermore, it has recently been reported in the Ivory Coast and Benin in West Africa (Madder et al. 2007, 2012).

The distribution of R. microplus in Africa seems to be related, amongst other factors, to warm summers and high annual rainfall, it can, however, survive during long dry periods in winter (Estrada-Pen a et al. 2006; Nyangiwe et al. 2011). These broad climatic requirements together with the trade in live cattle and goats may facilitate its introduction and establishment in previously uninfested countries. The current investigation was initiated with the aim of detecting the presence of R. microplus in Namibia. 
Materials and methods

Study area

Permits were obtained from the Namibian Ministry of Environment and Tourism (ref no. 1791/2013) and from the Department of Agriculture, Forestry and Fisheries in South Africa (Veterinary import permit ref no. 13/1/1/30/2/10/6-474). Sampling took place towards the end of summer (25 March-6 April 2013). Participating farms were identified through various veterinary practices and by word of mouth. Eighteen commercial livestock farms representing the south-central, central and north-central region of the country took part in the study. The survey cattle comprised several breeds, including Bonsmara, Brahman, Hereford, Nguni and various cross breeds. Mainly adult animals were included in the study.

Tick collection and identification

Ticks were collected from three to five animals per farm. The entire body was examined with special attention paid to the lower perineum and dewlap. The aim was to collect at least ten adult male ticks from each animal. The ticks were placed in pre-labelled tubes filled with 100 $\%$ ethanol. The label included the reference code for the animal and for the farm. Geographic co-ordinates, breed, animal age, sex and herd history were recorded separately.

Using a stereoscopic microscope, all adult ticks were initially identified to species level at Stellenbosch University, South Africa. Thereafter, all specimens of R. microplus were sent to the Faculty of Veterinary Science, University of Pretoria, South Africa for confirmation.

\section{Results}

Tick collection

In total 142 adult $\mathrm{R}$. microplus were collected from 20 cattle on four farms, whereas $\mathrm{R}$. decoloratus was present on all 18 of the survey farms (Table 1). The four farms were situated in the central part of Namibia (north and east of Windhoek). Although not sampled quantitatively, it would seem that few R. microplus were present on two of the farms, with larger numbers of ticks collected from cattle on the other two (Table 1).

Table 1 Collection dates, cattle breeds and tick data for four farms in Namibia in 2013

\begin{tabular}{|c|c|c|c|c|c|c|c|c|c|}
\hline \multirow[t]{2}{*}{ No } & \multicolumn{2}{|c|}{ Geo-reference } & \multirow[t]{2}{*}{ Date of collection } & \multirow[t]{2}{*}{ Breed } & \multirow[t]{2}{*}{ Sex } & \multicolumn{2}{|c|}{ R. microplus } & \multicolumn{2}{|c|}{ R. decoloratus } \\
\hline & Latitude & Longitude & & & & Male & Female & Male & Female \\
\hline 1 & $\mathrm{~S} 20^{\circ} 35.9^{\prime}$ & $\mathrm{E} 17^{\circ} 27^{\prime}$ & $28 / 03 / 2013$ & Herefords & F & 18 & 14 & 11 & 32 \\
\hline 2 & $\mathrm{~S} 21^{\circ} 26^{\prime}$ & $\mathrm{E} 15^{\circ} 56^{\prime}$ & $02 / 04 / 2013$ & Bonsmara & F & 5 & 4 & 7 & 10 \\
\hline 3 & $\mathrm{~S} 20^{\circ} 53^{\prime}$ & $\mathrm{E} 16^{\circ} 11^{\prime}$ & $02 / 04 / 2013$ & Bonsmara & M & 6 & 7 & 24 & 65 \\
\hline 4 & $\mathrm{~S} 22^{\circ} 26^{\prime}$ & $\mathrm{E} 18^{\circ} 58^{\prime}$ & $04 / 04 / 2013$ & Mixed & $F$ & 42 & 31 & 14 & 54 \\
\hline
\end{tabular}




\section{Discussion}

The recorded distribution of R. microplus in southern Africa includes South Africa, Swaziland, Zimbabwe and southern Mozambique (Mason and Norval 1980; Howell et al. 1978; Wedderburn et al. 1999; Horak et al. 2009). It is also present in Zambia and Madagascar (Berkvens et al. 1998; Estrada-Peña et al. 2006). However, its presence has as yet not been reported in Lesotho, Botswana, Namibia and Angola.

Rhipicephalus microplus was most probably introduced into Namibia from South Africa. The four farmers from whose cattle it was collected all mentioned that they had previously brought in cattle from South Africa or had bought cattle in Namibia that had a South African history. There has been a ban on the import of cloven-hoofed animals from South Africa since November 2010, due to an outbreak of foot-and-mouth disease in South Africa. The introductions must therefore have taken place prior to this date. The owners of the first three farms listed in Table 1 mentioned that they had bought bulls in South Africa during 2005 and 2007. The fourth farm is a dairy farm on which mortalities, confirmed as due to redwater (caused by Babesia bovis and B. bigemina), had occurred during June 2012. Approximately a month prior to the mortalities the farmer had purchased cattle from a neighbouring dairy farm. According to the farmer, these animals had been bought in North-West Province, South Africa, in 2005. In a survey on the distribution of ticks in this province, conducted over a number of years, commencing in 2001, Spickett et al. (2011) recorded R. microplus at 14 localities, thus supporting the possibility of its introduction into Namibia from here.

The co-occurrence of R. decoloratus at all four positive localities suggests that R. microplus might not completely displace the endemic Africa blue tick in Namibia. It is currently unclear as to how and why R. microplus displaces R. decoloratus at some localities, as reported in Zambia (Berkvens et al. 1998), Swaziland (Wedderburn et al. 1999), southern Mozambique (Horak et al. 2009) as well as at certain localities in South Africa (T\&nnesen et al. 2004; Nyangiwe and Horak 2007), while this is not the case at other localities, even within the same country. For instance, although R. microplus was the dominant species, both ticks remained present on cattle and the vegetation during a 5 year study on an experimental farm in the Stutterheim district in the Eastern Cape Province of South Africa (Nyangiwe et al. 2011).

Acknowledgments The authors would like to thank the farmers for their willingness to exchange information and agreeing to the collection of ticks from their animals. We also express our gratitude to Dr Andreas Gaugler, Gail Morland, Monique Rentel and their respective families for logistical support. Stel-lenbosch University and the National Research Foundation (IFR2011032500004) are thanked for infra-structural and financial support. The Grantholder acknowledges that opinions, findings and conclusions or recommendations expressed in any publication generated by the NRF supported research are that of the authors, and that the NRF accepts no liability whatsoever in this regard.

\section{References}

Bedford GAH (1932) A synoptic check-list and host-list of the ectoparasites found on South African Mammalia, Aves, and Reptilia (2nd edn). 18th Report of the Director of Vet Serv Anim Ind, Union of South Africa, pp 223-523

Berkvens DL, Geysen DM, Chaka G, Madder M, Brandt JRA (1998) A survey of the ixodid ticks parasitizing cattle in the Eastern Province of Zambia. Med Vet Entomol 12:234-240

Estrada-Peña A, Bouattour A, Camicas JL, Guglielmone A, Horak I, Jongejan F, Latif A, Pegram R, Walker AR (2006) The known distribution and ecological preferences of the tick subgenus Boophilus (Acari: Ixodidae) in Africa and Latin America. Exp Appl Acarol 38:219-235 
Horak IG, Nyangiwe N, De Matos C, Neves L (2009) Species composition and geographic distribution of ticks infesting cattle, goats and dogs in a temperate and a subtropical coastal region of south-eastern Africa. Onderstepoort J Vet Res 76:263-278

Howard CW (1908) A list of the ticks of South Africa, with descriptions and keys to all the forms known. Ann Transvaal Mus 1:73-188

Howell CJ, Walker JB, Nevill EM (1978) Ticks, mites and insects infesting domestic animals in South Africa. Part 1. Descriptions and biology. Department of Agricultural Technical Services, Republic of South Africa, Science Bulletin, no. 393, pp 69

Lange G, Barnes JI, Motinga DJ (1997) Cattle numbers, biomass, productivity, and land degradation in the commercial farming sector of Namibia, 1915-1995. DEA research discussion paper 17. Ministry of Environment and Tourism, Windhoek

Madder M, Thys E, Geysen D, Baudoux C, Horak I (2007) Boophilus microplus ticks found in West Africa. Exp Appl Acarol 43:233-234

Madder M, Adehan S, De Deken R, Adehan R, Lokossou R (2012) New foci of Rhipicephalus microplus in West Africa. Exp Appl Acarol 56:385-390

Mason CA, Norval RAI (1980) The ticks of Zimbabwe. 1. The genus Boophilus. Zimb Vet J 11:36-43

Nyangiwe N, Horak IG (2007) Goats as alternative hosts of cattle ticks. Onderstepoort J Vet Res 74:1-7

Nyangiwe N, Goni S, Herve'-Claude LP, Ruddat I, Horak IG (2011) Ticks on pastures and on two breeds of cattle in the Eastern Cape Province, South Africa. Onderstepoort J Vet Res 78(1), Art. \#320, 9 pages. doi:10.4102/ojvr.v78i1.320

Spickett AM, Heyne IH, Williams R (2011) Survey of the livestock ticks of the North West province, South Africa. Onderstepoort J Vet Res 78(1), Art. \#305, 12 pages. doi: 10.4102/ovjr.v78i1.305

Tænnesen MH, Penzhorn BL, Bryson NR, Stoltsz WH, Masibigiri T (2004) Displacement of Boophilus decoloratus by Boophilus microplus in the Soutpansberg region, Limpopo Province, South Africa. Exp Appl Acarol 32:199-208

Theiler G (1949) Zoological Survey of the Union of South Africa: tick survey. Part II. Distribution of Boophilus (Palpoboophilus) decoloratus, the blue tick. Onderstepoort J Vet Sci Anim Ind 22: 255-268? 1 map

Theiler G (1962) The Ixodoidea parasites of vertebrates in Africa south of the Sahara (Ethiopian region). Project S 9958. Report to the director of veterinary services, Onderstepoort. Mimeographed Walker

JB, Keirans JE, Horak IG (2000) The genus Rhipicephalus (Acari, Ixodidae): a guide to the brown ticks of the world. Cambridge University Press, Cambridge 643 pp

Wedderburn PA, Jagger TD, McCartan B, Hunter AG (1999) Distribution of Boophilus species ticks in Swaziland. Trop Anim Health Prod 23:167-171 